\title{
Pembentukan dan Pelatihan Kader Siaga Rabies di Kelurahan Palas Kota Pekanbaru
}

\author{
Rusherina ${ }^{1}$, Tesha Hestyana Sari*2 \\ 1,2Poltekkes Kemenkes Riau \\ *e-mail: icherusherina@gmail.com ${ }^{1}$, tesha@pkr.ac.id ${ }^{2}$
}

\begin{abstract}
One of the main goals of the Healthy Indonesia Program is controlling infectious diseases. Infectious diseases that are still problematic, namely rabies. In 2018 in Riau the provision of antirabies vaccines to victims of Animal Bites of Rabies Patients reached 84.45\%. The general objective of this activity is to establish a Rabies Alert Cadre and Training on prevention and first aid for rabies-borne animal bites in Palas Village, Pekanbaru. The method used is training of cadres. The results obtained, the average cognitive value of rabies alert cadres are pre-test; $t 60.83$ and post-test scores; 86.58. Then, the average rating of cadre skills in first aid in rabiesborne animal bites was a pre-test of 55.87 and a post-test value of 85.93. Statistical test obtained a value of 0,000 ( $p$ <0.05). It can be concluded that there are significant differences before training and after training. The healthy alert cadre is expected to carry out at least once a month for regular dog examinations of the community in the Palas Kelurahan and to continue coordinating with related parties.
\end{abstract}

Keywords: Cadre Training, Rabies, Knowledge

\begin{abstract}
Abstrak
Sasaran pokok Program Indonesia Sehat salah satunya yaitu pengendalian penyakit menular. Penyakit menular yang masih bermasalah yaitu rabies. Tahun 2018 di Riau pemberian vaksin antirabies kepada korban Gigitan Hewan Penderita Rabies mencapai 84,45\%. Tujuan umum kegiatan ini membentuk Kader Siaga Rabies dan Pelatihan tentang pencegahan dan pertolongan pertama pada gigitan hewan penular rabies di Kelurahan Palas Pekanbaru. Metode yang digunakan adalah pelatihan kepada kader. Hasil yang diperoleh, rata-rata nilai kognitif kader siaga rabies yaitu pre-tes; 6 60,83 dan nilai post-test; 86,58. Kemudian, rata-rata penilaian keterampilan kader pada pertolongan pertama pada gigitan hewan penular rabies yaitu pre-test sebesar 55,87 dan nilai post-test sebesar 85,93. Uji statistik didapatkan nilai 0,000 ( $p<0,05)$. Dapat disimpulkan terdapat perbedaan yang signifikan sebelum diberikan pelatihan dan setelah diberikan pelatihan. Kader siaga sehat diharapkan melaksanakan minimal sekali sebulan untuk pemeriksaan anjing secara berkala terhadap masyarakat di Kelurahan Palas dan tetap berkoordinasi dengan pihak-pihak terkait.
\end{abstract}

Kata kunci: Pelatihan Kader, Rabies, Pengetahuan

\section{PENDAHULUAN}

Pembangunan kesehatan Indonesia pada periode 2015-2019 adalah Program Indonesia Sehat dengan sasaran meningkatkan derajat kesehatan dan status gizi masyarakat melalui melalui upaya kesehatan dan pemberdayaan masyarakat. Program Indonesia Sehat dilaksanakan dengan strategi pengarusutamaan kesehatan dalam pembangunan, penguatan promotif, preventif dan pemberdayaan masyarakat, dimana salah satu sasaran pokoknya adalah pengendalian penyakit baik penyakit menular maupun penyakit tidak menular (Kemenkes RI, 2015). Salah satu penyakit menular yang masih banyak ditemukan adalah rabies.

Rabies adalah satu diantara banyak penyakit zoonosis atau penyakit yang dapat menular dari hewan ke manusia. Penyakit ini dapat ditularkan oleh hewan yang sebelumnya telah terinfeksi rabies. Adapun hewan yang dapat menularkan rabies adalah anjing, rakun, monyet, rubah dan kelelawar (Yousaf, 2012).

Di Indonesia, sebanyak 25 dari 34 provinsi tertular rabies. Provinsi bebas rabies antara lain Papua, Papua Barat, Bangka Belitung, Kepulauan Riau, NTB, Jawa Tengah, DIY, Jawa Timur, dan DKI Jakarta (Purnamasari \& Putra, 2017). Selama periode 2011 - 2017, ada lebih 500.000 kasus Gigitan Hewan Penular Rabies (GHPR) yang dilaporkan di Indonesia dan sebanyak 836 positif rabies. Bahkan kematian akibat rabies pada manusia mencapai 100 orang per tahun yang sebagian besar menimpa anak-anak (Harian Kompas, 2018). 
Dikutip dari Surat Kabar Antara Riau tanggal 26 September 2018, Penanggung Jawab Program Rabies Dinas Kesehatan Provinsi Riau Egawati menyatakan bahwa Riau merupakan daerah endemis rabies. Tercatat pada tahun 2018 pemberian vaksin antirabies kepada korban GHPR mencapai $84,45 \%$. Kota Pekanbaru masih menjadi daerah paling tinggi terdapat kasus GHPR, dan hingga September 2018 tercatat ada 195 kasus. Hewan paling banyak adalah anjing sebanyak 99 kasus, kemudian kucing 79 kasus dan kera 7 kasus.

Menurut Kepala Bidang Peternakan Dinas Pertanian dan Perikanan Kota Pekanbaru Bapak M. Firdaus, kelurahan yang urgen untuk diberikan pendidikan kesehatan tentang pencegahan dan penatalaksanaan rabies adalah Kelurahan Palas. Kelurahan Palas terdiri dari 7 RW, Kelurahan Palas merupakan kelurahan dengan populasi anjing tertinggi di Kota Pekanbaru tahun 2016 yaitu sebanyak 1.034 ekor anjing dan dengan jumlah gigitan pada manusia tertinggi dibandingkan dengan kelurahan lainnya.

Berdasarkan permasalahan di atas, Poltekkes Kemenkes Riau melalui berkolaborasi dengan PSIK Universitas Riau, Dinas Kesehatan Kota Pekanbaru serta Dinas Pertanian dan Perikanan Kota Pekanbaru pada tanggal telah melaksanakan kegiatan Community Outreach atau pengabdian kepada masyarakat yang didukung oleh INDOHUN-USAID, berupa pemberian pendidikan kesehatan tentang pencegahan dan pertolongan pertama pada gigitan hewan penular rabies pada 25 orang warga RW 06 Kelurahan Palas dalam rangka mewujudkan Pekanbaru Bebas Rabies pada tahun 2020 serta mendukung program GERMAS. Kegiatan tersebut disambut dengan sangat antusias oleh warga Kelurahan Palas dan diperkuat dengan penandatanganan "Komitmen Anti Rabies" antara Tim Community Outreach dengan warga yang mengikuti pendidikan kesehatan.

Untuk keberlanjutan (Sustainability) kegiatan tersebut, ada beberapa rencana kegiatan yang disepakati antara Tim Community Outreach dengan warga beserta RT, RW dan Lurah Kelurahan Palas. Salah satunya adalah pembentukan dan pelatihan Kader Siaga Rabies, mengingat di Kelurahan tersebut belum ada Kader Siaga Rabies, Kelompok Pemelihara dan Pecinta Anjing atau Kelompok Peduli Rabies lainnya.

Infodatin Kemenkes RI menyatakan bahwa strategi eliminasi untuk mencapai Indonesia Bebas Rabies 2020 adalah dengan penerapan prinsip One Health yang salah satunya adalah kemitraan dengan melibatkan dukungan dan peran masyarakat, termasuk kader. Hal yang sama di peroleh data hasil penelitian Purnamasari, dkk (2017) menyatakan bahwa Pembentukan Kader Siaga Rabies sangat berperan dalam pencegahan dan pengendalian rabies karena komitmen dari berbagai pihak termasuk didalamnya kader dan masyarakat yang merupakan kunci dalam pengendalian rabies. Hasil penelitian dari Negara endemik rabies memperlihatkan juga bahwa pentingnya meningkatkan kesadaran masyarakat tentang rabies sebagai salah satu pencegahan dan pengendalian kejadian rabies (Ghosh, dkk, 2016). Masyarakat adalah faktor utama yang menentukan keberhasilan upaya pencegahan dan pengendalian rabies di suatu daerah. Pengetahuan, sikap dan perilaku yang kurang dari masyarakat menjadikan mereka rentan terhadap penularan rabies (Sopi, 2015). Selain itu, menurut Media (2011), perilaku seseorang didukung oleh dirinya sendiri serta lingkungan seseorang tersebut. Hal ini tentukan akan mempengaruhi individu dalam pencegahan kejadian rabies.

Pengabdian masyarakat yang telah penulis laksanakan pada tahun 2018 didapatkan informasi bahwa karakteristik pengetahuan kader RW 06 Kel. Palas tentang rabies masih rendah yaitu $60 \%$ dan keterampilan pertolongan pertama pada gigitan yaitu 59\%. Evaluasi kegiatan pengabdian masyarakat ini mendapatkan respon yang sangat postif baik dari kader maupun dari masyarakat RW. 06 Kel. Palas. Hal ini terbukti dengan masih aktifnya kegiatan kader siaga rabies hingga sekarang dan masyarakat berterimakasih karena telah membekali mereka keterampilan pertolongan pertama gigitan anjing dimana lingkungan tempat tinggal mereka yang notabene tiap rumah pasti memelihara anjing.

Kemudian tahun 2019 penulis melanjutkan pengabdian kepada masyarakat di RW 04 Kelurahan Palas. Berdasarkan hasil wawancara dengan petugas kelurahan Palas didapatkan data 
bahwa terdapat 1 kasus gigitan anjing di RW 04 pada bulan Desember 2018, kader di RW 04 belum pernah diberikan pendidikan kesehatan tentang penanganan pertolongan pertama pada kasus gigitan anjing, jumlah Kepala Keluarga (KK) di RW 04 ada sekitar 450 KK dan setiap KK memiliki minimal 1 anjing, artinya populasi anjing di RW 04 berjumlah kurang lebih 450 ekor anjing. Di kelurahan tersebut, terutama di RW 04, warga seringkali tidak membawa anggota keluarganya ke fasilitas kesehatan setelah digigit anjing, jarang melaporkan tentang gigitan ke Dinas Pertanian dan Perikanan Kota Pekanbaru, beberapa warga tidak mengetahui tanda dan gejala rabies serta cara pertolongan pertama setelah gigitan hewan penular rabies serta belum terbentuknya Kader Siaga Rabies.

Berdasarkan hal tersebut maka perlu dilakukan pembentukan dan pelatihan kader siaga rabies di RW 04 Kelurahan Palas Kota Pekanbaru. Adapun tujuan umum dari kegiatan pengabdian kepada masyarakat ini adalah untuk membentuk Kader Siaga Rabies dan memberikan Pelatihan tentang pencegahan dan pertolongan pertama pada gigitan hewan penular rabies kepada Kader Siaga Rabies di RW. 4 Kelurahan Palas, Kota Pekanbaru tahun 2019. Sementara itu tujuan khususnya membentuk Kader Siaga Rabies di Kelurahan Palas, mengidentifikasi karakteristik anggota Kader Siaga Rabies di Kelurahan Palas, mengidentifikasi pengetahuan dan kerampilan anggota Kader Siaga Rabies tentang pencegahan dan pertolongan pertama pada gigitan hewan penular rabies di Kelurahan Palas sebelum pelatihan, melakukan pelatihan Kader Siaga Rabies tentang pencegahan dan pertolongan pertama pada gigitan hewan penular rabies di Kelurahan Palas dan mengevaluasi pengetahuan dan kerampilan anggota Kader Siaga Rabies tentang pencegahan dan pertolongan pertama pada gigitan hewan penular rabies di Kelurahan Palas setelah pelatihan

Direktorat Bina Peran Serta Masyarakat Depkes RI memberikan batasan tentang pengertian kader, yaitu "Kader adalah warga masyarakat setempat yang dipilih dan ditinjau oleh masyarakat dan dapat bekerja secara sukarela". Kader direkrut dari, oleh dan untuk masyarakat, yang bertugas membantu kelancaran pelayanan kesehatan (Putu, 2010). Kader merupakan tenaga masyarakat yang dianggap paling dekat dengan masyarakat. Departemen kesehatan membuat kebijakan mengenai latihan untuk kader yang dimaksudkan untuk meningkatkan pengetahuan. Para kader seyogyanya memiliki latar belakang pendidikan yang cukup sehingga memungkinkan mereka untuk membaca, menulis dan menghitung secara sederhana. Selain dapat bekerja secara sukarela dan mendapat kepercayaan dari masyarakat kader harus mempunyai kredibilitas yang baik dimana perilakunya menjadi panutan masyarakat, memiliki jiwa pengabdian yang tinggi, mempunyai penghasilan tetap, sanggup membina masyarakat sekitarnya. Kader mempunyai peran yang besar dalam upaya meningkatkan kemampuan masyarakat menolong dirinya untuk mencapai derajat kesehatan yang optimal (Putu, 2010).

Mekanisme pembentukan kader membutuhkan kerjasama tim. Hal ini disebabkan karena kader yang akan dibentuk terlebih dahulu harus diberikan pelatihan kader. Pelatihan kader ini diberikan kepada para calon kader di desa yang telah ditetapkan. Sebelumnya telah dilaksanakan kegiatan persiapan tingkat desa berupa pertemuan desa, pengamatan dan adanya keputusan bersama untuk terlaksanakan acara tersebut. Persiapan dari pelatihan kader ini adalah calon kader yang akan dilatih, waktu pelatihan sesuai kesepakatan bersama, tempat pelatihan yang bersih, terang, segar dan cukup luas, adanya perlengkapan yang memadai, pendanaan yang cukup serta adanya tempat praktik (lahan praktik bagi kader) (Putu, 2010).

Tim pelatihan kader melibatkan dari beberapa sektor. Camat otomatis bertanggung jawab terhadap pelatihan ini, namun secara teknis oleh kepala Puskesmas. Pelaksanaan harian pelatihan ini adalah staf puskesmas yang mampu melaksanakan. Adapun pelatihannya adalah tanaga kesehatan, petugas KB (PLKB), pertanian, agama, PKK, dan sektor lain. Waktu pelatihan ini membutuhkan 32 jam atau disesuaikan. Metode yang digunakan adalah ceramah, diskusi, simulasi, demonstrasi, pemainan peran, penugasan, dan praktik lapangan (Putu, 2010).

Pembentukan Kader Siaga Rabies ini diharapkan sangat berperan dalam pencegahan dan pengendalian rabies, karena komitmen dari berbagai pihak termasuk didalamnya kader dan masyarakat merupakan kunci dalam pengendalian rabies (Purnamasari \& Putra, 2017). Dalam 
upaya pencegahan dan pengendalian rabies, di beberapa kabupaten di Indonesia telah dibentuk Kader Siaga Rabies atau Kader Anti Rabies. Salah satu contoh, Departemen Ilmu Penyakit Hewan dan Kesmavet IPB (2017) telah melakukan pembentukan dan pelatihan Kader Siaga Rabies (KASIRA) untuk mendukung Jawa Barat Bebas Rabies Tahun 2020.

Kader Siaga Rabies memiliki beberapa tugas. Tugas tersebut adalah 1) Secara berkala melakukan edukasi/ penyuluhan kesehatan kepada masyarakat yang belum mendapatkan informasi tentang pencegahan dan pertolongan pertama pada gigitan hewan penular rabies, 2) Berkoordinasi dengan pihak Puskesmas terkait pertolongan pertama pada gigitan hewan penular rabies, serta 3) Membantu warga dalam pelaporan setiap kejadian gigitan kepada Dinas Perternakan yang terkait.

\section{METODE}

Kegiatan pengabdian kepada masyarakat ini dilaksanakan pada bulan April sampai Juli 2019. Lokasi kegiatan pengabdian kepada masyarakat ini dilaksanakan di RW 04 Kelurahan Palas Kota Pekanbaru. Sarana yang digunakan dalam kegiatan ini meliputi ruang aula kelurahan. Alat utama yang digunakan adalah laptop, infokus, alat tulis, leaflet bahan dan alat demonstrasi (Air mengalir di dalam galon berkran, sabun, handscoen, betadine, alkohol, tissue). Pendekatan atau metode yang dipakai adalah penyuluhan kesehatan dan pelatihan keterampilan dilakukan sebanyak 2 kali kegiatan. Penyuluhan adalah suatu upaya yang dilakukan untuk mendorong terjadinya perubahan pada individu, kelompok, komunitas atau masyarakat dengan tujuan mereka tahu, mau serta mampu menyelesaikan permasalahan yang terjadi (Amanah, 2007 dalam Dilago, 2019). Variabel yang diamati adalah pengetahuan dan keterampilan kader setelah diberikan pengetahuan tentang pencegahan dan pertolongan pertama pada gigitan hewan penular rabies dan dianalisa menggunakan uji Paired Sample t-test.

\section{HASIL DAN PEMBAHASAN}

Berikut hasil dari pre-test dan post-test pengetahuan dan keterampilan anggota Kader Siaga Rabies tentang pencegahan dan pertolongan pertama pada gigitan hewan penular rabies di Kelurahan Palas. Pre-test dan post-test secara tertulis sebanyak 15 soal dan uji keterampilan mendemonstrasikan pertolongan pertama pada gigitan hewan penular rabies sesuai dengan SOP.

Tabel 1. Hasil Pre-Test dan Post-Test Kognitif Kader

\begin{tabular}{ccc}
\hline Variabel & Mean \pm Std. Deviation & P-Value \\
\hline Nilai Pre-test & $60,83 \pm 11,22$ & $0.000^{*}$ \\
Nilai Post-test & $86,58 \pm 7,12$ & \\
\hline
\end{tabular}

Ket : Ada perbedaan yang signifikan dalam uji paired sample t-test $(\propto<0.05)$

Tabel 2. Hasil Pre-Test dan Post-Test Keterampilan Kader

\begin{tabular}{ccc}
\hline Variabel & Mean \pm Std. Deviation & P-Value \\
\hline Nilai Pre-test & $55,87 \pm 6,12$ & $0.000^{*}$ \\
Nilai Post-test & $85,93 \pm 4,43$ & \\
\hline
\end{tabular}

Ket : Ada perbedaan yang signifikan dalam uji paired sample t-test $(\propto<0.05)$

Berdasarkan hasil uji Paired Sample t-test yang dilakukan pada nilai Pre dan Post, didapatkan hasil bahwa terdapat perbedaan pengetahuan antara sebelum diberikan pendidikan kesehatan dan keterampilan dengan sesudah diberikan pendidikan kesehatan dan keterampilan. 
Jika dibandingkan dengan hasil pre-test, dapat dilihat bahwa terdapat peningkatan hasil evaluasi kognitif maupun keterampilan.

Kader Siaga Rabies di Kelurahan Palas sudah terbentuk dengan jumlah 15 orang. Mekanisme pembentukan Kader Siaga Rabies ini sesuai dengan yang dinyatakan oleh Putu (2010), bahwa mekanisme pembentukan kader membutuhkan kerjasama tim, yang sebelumnya telah dilaksanakan kegiatan persiapan tingkat desa berupa pertemuan desa, pengamatan dan adanya keputusan bersama sesuai dengan kriteria terpilihnya seseorang menjadi kader yaitu: mampu membaca, menulis dan menghitung, dapat bekerja secara sukarela, dan mendapat kepercayaan dari masyarakat.

Pembentukan Kader Siaga Rabies diharapkan sangat berperan dalam pencegahan dan pengendalian rabies, karena komitmen dari berbagai pihak termasuk didalamnya kader dan masyarakat merupakan kunci dalam pengendalian rabies (Purnamasari \& Putra, 2017). Pelatihan Kader Siaga Rabies tentang pencegahan dan pertolongan pertama pada gigitan hewan penular rabies di Kelurahan Palas sudah terlaksana dengan baik dan lancar. Kegiatan ini diawali terlebih dahulu dengan berbagai persiapan meliputi kesepakatan waktu dan tempat dengan Kader Siaga Rabies serta stakeholders, persiapan tempat, sarana dan peralatan yang dibutuhkan seperti: modul tentang Kader Siaga Rabies, penyakit rabies, pencegahan dan pertolongan pertama pada gigitan hewan penular rabies, Bahan tayang/ PPT laptop dan infokus, microphone dan speaker, spanduk, bahan dan alat demonstrasi (Air mengalir di dalam gallon berkran, sabun, handscoen, betadine, alkohol, tissue), soal pre-test dan post-test serta poster.

Persiapan kegiatan diperlukan sebelum kegiatan pelatihan kader agar dapat berjalan lancar dan mencapai tujuan yang diinginkan. Hal ini sesuai dengan teori yang menyatakan bahwa diperlukan persiapan dari pelatihan kader meliputi: calon kader yang akan dilatih, waktu pelatihan sesuai kesepakatan bersama, tempat pelatihan yang bersih, terang, segar dan cukup luas, adanya perlengkapan yang memadai, pendanaan yang cukup dan danya tempat/lahan praktik bagi kader (Putu, 2010).

Metode pelatihan yang digunakan adalah ceramah, diskusi dan demonstrasi. Metode ini dapat dikatakan efektif dan cocok digunakan untuk materi pelatihan yang telah disiapkan. Hal ini terbukti dari hasil evaluasi proses yang menunjukkan bahwa peserta pelatihan memberikan respon positif, bersemangat dan sangat antusias mengikuti pelatihan; tidak ada yang meninggalkan ruangan dan banyaknya pertanyaan yang diajukan. Metode ceramah bervariasi merupakan metode yang efektif untuk meningkatkan pengetahuan masyarakat (Jatmiko dkk, 2018).

Mayoritas karakteristik Kader Siaga Rabies adalah perempuan sebanyak 14 orang $(93,3 \%)$, berada pada umur $>40$ tahun sebanyak 9 orang $(60 \%)$, berpendidikan SMU/SMK sebanyak 12 orang (80\%) dan memiliki pekerjaan sebagai IRT sebanyak 12 orang (80\%). Direktorat Bina Peran Serta Masyarakat Depkes RI menyatakan bahwa "Kader adalah warga masyarakat setempat yang dipilih dan ditinjau oleh masyarakat dan dapat bekerja secara sukarela". Kader direkrut dari, oleh dan untuk masyarakat, yang bertugas membantu kelancaran pelayanan kesehatan. Kader merupakan tenaga masyarakat yang dianggap paling dekat dengan masyarakat. Para kader seyogyanya memiliki latar belakang pendidikan yang cukup sehingga memungkinkan mereka untuk membaca, menulis dan menghitung secara sederhana. Selain dapat bekerja secara sukarela dan mendapat kepercayaan dari masyarakat kader harus mempunyai kredibilitas yang baik dimana perilakunya menjadi panutan masyarakat, memiliki jiwa pengabdian yang tinggi, mempunyai penghasilan tetap, sanggup membina masyarakat sekitarnya (Putu, 2010).

Berdasarkan karakteristik Kader Siaga Rabies yang telah diuraikan diatas dapat dilihat bahwa secara umum karakteristik kader sesuai dengan yang dikriteriakan, terutama memiliki latar belakang pendidikan yang cukup untuk menyerap dan menyampaikan informasi yang telah diperoleh pada pelatihan. Namun, diantara anggota Kader Siaga Rabies ada dua orang yang memiliki pendidikan SD. Hal ini diharapkan tidak akan menjadi kendala, karena seseorang 
yang memiliki pendidikan SD dapat membaca, menulis dan menghitung secara sederhana dan pemilihan dua orang tersebut sebagai Kader Siaga Rabies tentunya sudah dipilih dan mendapat kepercayaan dari masyarakat untuk dapat bekerja secara sukarela.

Mayoritas anggota Kader Siaga Rabies adalah perempuan dengan pekerjaan sebagai IRT. Hal ini tentunya akan lebih mendukung keberhasilan tugas Kader Siaga Rabies, karena IRT diasumsikan memiliki lebih banyak waktu untuk berbagi informasi dengan masyarakat di Kelurahan Palas, terutama dalam melaksanakan tiga tugas Kader Siaga Rabies yaitu: 1) Secara berkala melakukan edukasi/ penyuluhan kesehatan kepada masyarakat yang belum mendapatkan informasi tentang pencegahan dan pertolongan pertama pada gigitan hewan penular rabies, 2) Berkoordinasi dengan pihak Puskesmas terkait pertolongan pertama pada gigitan hewan penular rabies, serta 3) Membantu warga dalam pelaporan setiap kejadian gigitan kepada Dinas Perternakan yang terkait.

Berdasarkan tabel 1. dapat dilihat bahwa rata-rata nilai Kognitif (ujian tulis) kader siaga rabies tentang pencegahan dan pertolongan pertama pada gigitan hewan penular rabies di Kelurahan Palas yaitu pre-test sebesar 60,83 dan nilai post-test sebesar 86,58. Hasil ini memperlihatkan adanya perbedaan antara pre-test dan post-test sebesar 25,75 . Sementara itu, tabel 2. juga memperlihatkan bahwa rata-rata penilaian keterampilan kader pada pertolongan pertama pada gigitan hewan penular rabies yaitu pre-test sebesar 55,87 dan nilai post-test sebesar 85,93. Hasil ini memperlihatkan adanya perbedaan antara pre-test dan post-test penilaian keterampilan sebesar 30,06. Hasil uji statistik didapatkan nilai $0,000(p<0,05)$ yang dapat disimpulkan terdapat perbedaan yang signifikan sebelum diberikan pelatihan dan setelah diberikan pelatihan.

Berdasarkan hasil Jika dibandingkan dengan hasil pre-test, dapat dilihat bahwa terdapat peningkatan hasil evaluasi kognitif maupun keterampilan. Peningkatan ini dapat disebabkan oleh beberapa hal. Pertama, metode pelatihan yang meliputi ceramah, diskusi dan demonstrasi yang digunakan cukup tepat sehingga membuat peserta mudah memahami materi yang diberikan. Kedua, bahan tayang/ PPT yang disajikan cukup menarik, mudah dipahami, dan tidak membuat bosan peserta. Hasil ini didukung oleh hasil penelitian Yulinda (2018) tentang efektifitas penyuluhan metode ceramah dan audiovisual dimana hasilnya memperlihatkan terdapat peningkatan pengetahuan dan sikap responden. Ketiga, peserta diberikan modul untuk dipelajari dirumah, kemudian seminggu setelah itu dilakukan post-test, sehingga peserta lebih memahami materi yang diberikan. Keempat, peserta memiliki semangat dan antusiasme yang tinggi untuk mengikuti dan mendalami materi pelatihan Kader Siaga Rabies, mengingat angka penyakit rabies yang masih tinggi di Kelurahan Palas.

Di sisi lain, masih terdapat peserta yang memiliki nilai di bawah rata-rata. Jika dianalisis dari segi karakteristik, hal tersebut dapat disebabkan oleh faktor usia dan latar belakang pendidikan peserta tersebut. Berdasarkan hasil pengabdian masyarakat oleh Hidayati (2019), para kader memiliki kemauan yang baik dalam melihat serta membaca leaflet, poster, dan banner. Namun demikian, media tersebut tidak mempunyai hubungan yang nyata dengan tingkat pengetahuan dan sikap kader.

Berdasarkan hasil penelitian Aryana (2012), salah satu faktor yang dapat memberikan kontribusi terhadap pemberantasan rabies adalah memberdayakan serta melibatkan para tokoh formal, tokoh informal dan masyarakat dalam peningkatan wawasan pengetahuan tentang rabies berupa berbagai bentuk pelatihan. Hasil penelitian tersebut mendukung tim pengabdian masyarakat penulis untuk melaksanakan pelatihan kader siaga rabies secara kontinu. Hal ini juga didukung oleh hasil penelitian Nugroho dkk (2013) yang menjelaskan bahwa adanya peningkatan pengetahuan masyarakat tentang rabies, kesadaran mencari pengobatan medis, serta memberikan laporan pasca terkena gigitan akan memberikan kontribusi dalam menurunkan kasus gigitan serta kematian oleh rabies pada manusia. Hasil penelitian lainnya oleh Ali (2013) \& Sarjana (2018) juga mendukung kegiatan pengabmas penulis, dimana penelitiannya 
menunjukkan hasil: terdapat hubungan yang signifikan antara tingkat pengetahuan dan sikap terhadap tindakan pencegahan penyakit rabies pada masyarakat.

\section{KESIMPULAN}

Berdasarkan hasil pre-test dan post-test, rata-rata nilai kognitif kader siaga rabies tentang pencegahan dan pertolongan pertama pada gigitan hewan penular rabies yaitu pre-test sebesar 60,83 dan nilai post-test sebesar 86,58 . Sementara itu, untuk rata-rata penilaian keterampilan kader pada pertolongan pertama pada gigitan hewan penular rabies yaitu pre-test sebesar 55,87 dan nilai post-test sebesar 85,93 . Hasil uji statistik dari nilai pre test dan post-test didapatkan nilai $0,000(\mathrm{p}<0,05)$. Hasil ini disimpulkan terdapat perbedaan yang signifikan sebelum diberikan pelatihan dan setelah diberikan pelatihan. Diharapkan kepada Kader Siaga Rabies agar dapat melaksanakan minimal sekali dalam satu bulan dalam pencegahan dan pertolongan pertama pada gigitan hewan penular rabies dan pemeriksaan anjing secara berkala terhadap masyarakat di Kelurahan Palas dengan tetap berkoordinasi dengan pihak-pihak terkait. Selain itu diharapkan juga agar kegiatan Pengabdian Kepada Masyarakat ini dapat berlanjut di tahun berikutnya dengan tetap melakukan Pembentukan dan Pelatihan Kader Siaga Rabies di RT lain di Kelurahan Palas, sehingga untuk beberapa tahun mendatang dapat mencapai Kelurahan Palas Bebas Rabies.

\section{DAFTAR PUSTAKA}

Ali A, Ahmed EY, Sifer D (2013). A Study on Knowledge, Attitude and Practice of rabies among residents in Addis Ababa, Ethiopia. Ethiopia Veterinary Journal, 17(2), 19-35.

Aryana, dkk. (2012). Analisis Faktor-Faktor yang dipertimbangkan Masyarakat dalam Pemberantasan Virus Rabies di Wilayah Kerja Puskesmas Kediri I Tabanan Tahun 2011. Jurnal Skala Husada, 9(1), 51-59.

Dilago, Zakarias. (2019). Penyuluhan dan Pelaksanaan Vaksinasi Rabies di Desa Tagalaya Kecamatan Tobelo. Jurnal Pengabdian Masyarakat Darma Bakti Teuku Umar, 1(1).

Ghosh S, Chowdhury S, Haider N, Bhowmik RK, Rana MS, Marma ASP, Hossain MB, Debnath NC, Ahmed BN. (2016). Awareness of Rabies and Response to Dog Bites In a Bangladesh Community. Veterinary Medicine and Science. 2:161-169.

Hidayati, Fitri.,dkk. (2019). Intervensi Penyuluhan dengan Metode Ceramah dan Buzz untuk Peningkatkan Pengetahuan dan Sikap Kader Posyandu dalam Pengendalian Rabies di Kabupaten Sukabumi. Jurnal Penyuluhan, 15(1), 65-74.

Jatmiko, Safari W.,dkk. (2018). Pengaruh Metode Ceramah dalam Meningkatkan Pengetahuan Masyarakat terhadap Penyakit Tuberkulosis. Jurnal Litbang Sukowati, 2(1), 1-7.

Media Y, Trinabasilih, Syaiful Sofyan. (2011). Pengetahuan, Sikap dan Perilaku Kaitannya Dengan Penularan dan Pencegahan Malaria di Kabupaten Kepualauan Mentawai, Provinsi Sumatera Barat. Jurnal Ekologi Kesehatan, 10(3), 187-194.

Nugroho DK., dkk. (2013). Analisis Data Surveilans Rabies (2008-2011) di Propinsi Bali, Indonesia. Outbreak, Survaillance and Investigation Reports (OSIR), 6(2), 8-12

Purnamasari, L. \& Putra, K. A. D. (2017). Pengendalian dan manajemen rabies pada manusia di area endemik. Continuing Professional Development, Vol. 44 (1), 66-69.

Sarjana, Ni Kadek AS.,dkk. (2018). Hubungan antara Tingkat Pengetahuan dan Sikap dengan Tindakan Pencegahan Penyakit Rabies pada Warga di Wilayah Puskesmas Kuta II. SMART MEDICAL JOURNAL, 1(1), eISSN : 2621-0916

Sopi, Ira IPB., \& Mau, F. (2016). Pengetahuan sikap dan perilaku masyarakat dalam kaitannya dengan kejadian rabies di Kabupaten Flores Timur, Sikka, Manggarai dan Ngada, Provinsi Nusa Tenggara Timur Knowledge, attitudes and behavior related to the incidenceof rabies in Flores Timur R. JHECDs, 1(1), 1-7.

Yousaf MZ, Qasim M, Zia S, Khan R, Ashfaq U,Khan S (2012). Rabies Molecular Virology, Diagnosis, Prevention, and Treatment. Virology Journal, 9 (50). 
Yulinda, arif \& Fitriyah, Nurul. (2018). Efektivitas Penyuluhan Metode Ceramah dan Audiovisual dalam Meningkatkan Pengetahuan dan Sikap Tentang Sadari di SMKN 5 Surabaya. Jurnal Promkes, 6(2), 116-128

Bhakti SW (2018). Kemenkes : Banyak anak meninggal karena rabies. https://sains.kompas.com/read/2018/08/24/183100023/kemenkes--banyak-anakmeninggal-karena-rabies [10 Juni 2019]

Departemen Ilmu Penyakit Hewan dan Kesmavet IPB. (2017). Pelatihan Kader Siaga Rabies 2017. http://iphk.fkh.ipb.ac.id. [02 Maret 2019]

Putu. (2010). Sembilan macam kader kesehatan dalam pelayanan puskesmas. http://www.puskel.com/9-macam-kader-kesehatan-dalam-pelayanan-puskesmas/. Maret 2019]

Rian ,A (2018). Dinkes : Riau alami 5.328 kasus gigitan hewan rabies. http://www.antarariau.com/berita/104070/dinkes-riau-alami-5328-kasus-gigitan-hewanrabies. [27 Maret 2019]

Noferdiman. (2019). Pelatihan Manajemen Pemeliharaan Itik Kerinci Menuju Kawasan Sentra Produksi di Kabupaten Kerinci. Dinamisia: Jurnal Pengabdian Masyarakat, 3(Speciallssue), 192-19. https://doi.org/10.31849/dinamisia.v3i0.2934 